\title{
PENERAPAN LKS BERMUATAN NILAI-NILAI KARAKTER DALAM MODEL PEMBELAJARAN KOOPERATIF TIPE JIGSAW PADA KELAS XI DI SMA NEGERI 11 PADANG
}

\author{
Asrad Hafizah ${ }^{1)}$, Yenni Darvina ${ }^{2)}$, Masril ${ }^{2)}$ \\ ${ }^{1)}$ Mahasiswa Pendidikan Fisika, FMIPA Universitas Negeri Padang \\ ${ }^{2)}$ Staf Pengajar Jurusan Fisika, FMIPA Universitas Negeri Padang \\ email. asradhafizah@yahoo.co.id
}

\begin{abstract}
Achievements of mastery learning physics students at SMAN 11 Padang were not optimal.These are caused by less optimal learning activities, lack of cooperation, and undeveloped characters of students in the learning process. Moreover, learning model and teaching materials that commonly used have not been varied and Student Worksheet has not been charged character values. Therefore, this research aimed to determine the effect of applying the charged Student Worksheet character values in Jigsaw cooperative learning model in class XI SMAN 11 Physics Padang on learning outcomes of students's competency attitudes, knowledge, and skills.Type of research was a quasi-experimental (Quasi-Experimental Research) with a research design form was Randomized Control Group Only Design. Population were all students in class XI SMA MIA 11 Padang who registered academic year 2014/2015 with a cluster random sampling technique. The research instrument used a form of observation sheet on the attitude of competencies, a written test on knowledge competencies, and rubring scor on skills competencies. Data were analyzed using two similarity test average used was the t. The results showed that the average of students learning outcomes in experimental class and control class on all competencies were sequentially: (81.38) and (68.9), (80.25) and (75,23), and (74.78) and (66.9). Based on the hypothesis test on all competencies as compared with the value of $1.98 \mathrm{tt}$. Therefore, can be concluded that the hypothesis "There is a significant impact on the application of the Student Worksheet charged character values in Jigsaw cooperative learning model in class XI SMAN 11 Padang" received on the real level of 0.05.
\end{abstract}

Keywords : Student worksheet, Cooperative Learning, Jigsaw, Learning Outcomes

\section{PENDAHULUAN}

Fenomena berkembangnya ilmu pengetahuan dan teknologi secara pesat telah memunculkan persaingan dalam berbagai bidang kehidupan, diantaranya adalah bidang pendidikan. Sumber daya manusia yang bermutu tinggi dihasilkan dari pendidikan yang bermutu tinggi. Oleh karena itu, pemerintah melakukan usaha untuk meningkatkan mutu pendidikan, diantaranya adalah pengadaan sarana pendidikan dan prasarana pendidikan dan merevisi kurikulum, seperti Kurikulum Tingkatan Satuan Kompetensi (KTSP) direvisi menjadi Kurikulum 2013 yang menuntut adanya pembelajaran tuntas dengan mengacu kepada Kriteria Ketuntasan Minimum sehingga tujuan pendidikan nasional agar peserta didik tidak hanya memiliki kecerdasan intelektual, tetapi juga memiliki karakter terpuji tercapai.

Kurikulum 2013 menjanjikan lahirnya generasi yang produktif, kreatif, inovatif, dan berkarakter melalui proses pembelajaran interaktif, menyenangkan, dan memotivasi peserta didik untuk berpatisipasi aktif. Pembelajaran diarahkan agar peserta didik terlatih merumuskan masalah (bertanya), berfikir analitis (pengambilan keputusan), dan mampu bekerja sama dalam menyelesaikan masalah. Sehubungan dengan itu, Kurikulum 2013 menerapkan suatu pendekatan yaitu pendekatan saintifik yang meliputi lima pengalaman belajar yaitu: mengamati, menanya, mengumpulkan informasi/ mencoba, menalar, dan mengkomunikasikan $^{[1]}$, tetapi masih banyak sekolah yang belum menerapkan lima pengalaman belajar ini, salah satunya SMA Negeri 11 Padang.

Berdasarkan observasi yang telah peneliti lakukan di SMA Negeri 11 Padang terlihat bahwa pembelajaran Fisika belum optimal dan fasilitas yang digunakan belum memadai sehingga aktivitas peserta didik dalam proses pembelajaran masih jauh dari harapan. Selain itu, pencapaian hasil belajar peserta didik masih rendah yang dapat dilihat dari nilai ratarata ujian harian pertama Fisika peserta didik kelas XI MIA SMA Negeri 11 Padang tahun ajaran 2014/ 2015 sebagaimana terlihat dalam Tabel 1.

Tabel 1. Nilai Rata-rata UH I Fisika Peserta Didik Kelas XI MIA SMA Negeri 11 Padang

\begin{tabular}{|c|c|c|c|}
\hline No & Kelas & $\begin{array}{c}\text { Rata-rata Nilai } \\
\text { UH }_{1}\end{array}$ & KKM \\
\hline 1 & XI MIA $_{1}$ & 64,84 & \\
\cline { 1 - 2 } 2 & XI MIA $_{2}$ & 64,19 & \multirow{2}{*}{78} \\
\cline { 1 - 2 } 3 & XI MIA $_{3}$ & 63,75 & \\
\hline 4 & XI MIA $_{4}$ & 63,39 & \\
\hline
\end{tabular}




\begin{tabular}{|c|c|c|c|}
\hline No & Kelas & $\begin{array}{c}\text { Rata-rata Nilai } \\
\text { UH }_{1}\end{array}$ & KKM \\
\hline 5 & XI MIA $_{5}$ & 60,83 & \\
\hline
\end{tabular}

Berdasarkan Tabel 1 terlihat bahwa rata-rata nilai kelima kelas masih di bawah KKM. Rendahnya pencapaian peserta didik pada Tabel 1 disebabkan oleh proses pembelajaran yang belum melibatkan peserta didik secara optimal dalam kegiatan pembelajaran. Hal ini berkaitan dengan penyediaan fasilitas dalam proses pembelajaran. Salah satu fasilitas yang diperlukan dalam proses pembelajaran adalah bahan ajar. Salah satu bahan ajar yang praktis digunakan oleh guru adalah LKS. LKS penting dalam proses pembelajaran karena dapat membuka kesempatan bagi peserta didik untuk berperan aktif dalam proses pembelajaran.

Di SMA Negeri 11 Padang sebenarnya guru telah menggunakan LKS, tetapi LKS tersebut belum bermuatan nilai-nilai karakter sehingga peserta didik tidak mengetahui bahwa materi yang telah dipelajari sebenarnya memiliki nilai-nilai yang baik dalam pembentukan karakter peserta didik. Peserta didik beranggapan bahwa Fisika itu adalah mata pelajaran yang memuat rumus-rumus. LKS tersebut juga belum memenuhi standar LKS bahwa struktur LKS memuat judul, petunjuk belajar (petunjuk peserta didik), kompetensi yang akan dicapai, informasi pendukung, tugas, langkah kerja, dan penilaian ${ }^{[2]}$. Dampaknya adalah peserta didik hanya akan menghapal rumusrumus saja, belajar Fisika menjadi membosankan dan tidak ada motivasi dalam diri peserta didik untuk mempelajarinya. Padahal LKS ini diharapkan dapat memotivasi peserta didik untuk lebih paham pada konsep Fisika, lebih aktif dalam pembelajaran serta dapat mengerjakan soal-soal yang ada dalam LKS tersebut secara mandiri. Untuk mengatasi hal tersebut, maka LKS yang digunakan harus memenuhi struktur penulisan LKS dan bermuatan nilai-nilai karakter yang menyajikan nila-nilai karakter baik yang dilatihkan maupun yang digali dari materi.

LKS bermuatan nilai-nilai karakter ini disajikan seperti LKS biasa, tetapi dalam LKS disajikan nilainilai karakter baik yang dilatihkan maupun yang digali dari materi. Untuk nilai karakter yang dilatihkan dibuat berdasarkan kalimat seruan yang disajikan baik pada materi maupun sebelum diskusi dimulai. Sedangkan untuk nilai-nilai karakter yang digali dari materi disajikan diakhir isi LKS dalam bentuk kata renungan, dimana nilai karakter ini akan diungkapkan diakhir pembelajaran oleh guru.

Hal lain yang mempengaruhi kualitas proses pembelajaran adalah pemilihan model, strategi, dan metode pembelajaran. Pemilihan ini harus didasarkan bahwa setiap peserta didik memiliki kemampuan dan tingkat berfikir peserta didik yang berbeda sehingga pemilihan model, strategi, dan metode pembelajaran yang sesuai akan membantu peserta didik dalam memahami dan menguasai materi pembelajaran secara aktif dan terlatih di dalam kelompok sehingga tujuan kurikulum dapat tercapai. Setelah diperhatikan, di SMA Negeri 11 Padang masih menggunakan model, strategi, dan metode pembelajaran yang masih kurang optimal. Dalam proses pembelajaran peserta didik hanya sebagai pendengar, jarang bertanya ketika tidak paham pada materi yang disajikan, dan penerapan sistem kerja sama masih kurang sehingga peserta didik tidak terlatih bekerja sama dalam pembelajaran kelompok diskusi .

Berdasarkan hal tersebut dalam proses pembelajaran diperlukanya model, strategi, dan metode pembelajaran yang dapat mengoptimalkan aktivitas belajar peserta didik dan melatih peserta didik dalam kelompok. Salah satunya model pembelajaran adalah pembelajaran kooperatif yang dapat memaksimalkan aktivitas dan bekerja sama dalam kelompok secara kolaboratif yang bersifat heterogen. Salah satu tipe pembelajaran kooperatif adalah tipe Jigsaw. Pembelajaran kooperatif tipe Jigsaw merupakan suatu model pembelajaran dengan menitikberatkan pada kerja kelompok peserta didik dalam kelompoknya ${ }^{[3]}$. Berikut ini sintak pembelajaran Jigsaw yang dapat dilihat pada Tabel $2^{[4]}$.

Tabel 2. Fase-fase dalam Menerapkan Pembelajaran Jigsaw

\begin{tabular}{|l|l|}
\hline \multicolumn{1}{|c|}{ Fase } & Tujuan \\
\hline Fase1:Menunjuk & - Membuat kerangka kerja \\
Pakar & bagi kepingan-kepingan \\
Peserta didik & Jigsaw \\
diberikan materi & - Memberikan latihan \\
masing-masing & negosiasi sosial \\
untuk dipelajari & \\
secara mendalam & \\
\hline Fase 2: Mengum- & - Mengembangkan pema- \\
pulkan informasi & haman sedalam mungkin \\
Pakar berupa & terhadap komponen topik \\
siswa mempelajari & - Memberikan pengalaman \\
komponen topik & mengumpulkan dan me- \\
mereka sedalam & nyusun informasi \\
mungkin & - Membantu siswa mandiri \\
\hline Fase 3: Rapat & - Membandingkan dan \\
Ahli & menyusun informasi \\
Pakar dari setiap & - Memperdalam \\
komponen topik & pengetahuan tentang kom- \\
berkumpul dan & ponen spesifik suatu topik \\
menyiapkan pre- & - Mengembangkan \\
sentasi yang akan & kepemimpinan dan \\
mereka sajikan & keahlian interaksi sosial \\
kepada kelompok & \\
mereka & \\
\hline Fase 4: Instruksi & - Membangun pengetahuan \\
Rekan & latar belakang teman \\
Pakar mempresen- & kelompok terkait dengan \\
tasikan informasi & topik \\
tentang komponen & - Memberikan pengalaman \\
topik mereka & melakukan presentasi dan \\
kepada teman & berkomunikasi secara \\
kelompok mereka & jernih \\
\hline & \\
\hline
\end{tabular}




\begin{tabular}{|l|l|}
\hline \multicolumn{1}{|c|}{ Fase } & \multicolumn{1}{c|}{ Tujuan } \\
\hline Fase 5: Review & - Mengenali ciri-ciri utama \\
dan Penutup & topik \\
Topik dirivies dan & - Mengisi celah dalam \\
diringkas & pemahan siswa \\
\hline
\end{tabular}

Hal lain yang juga harus ada dalam proses pembelajaran adalah menumbuhkembangkan nilainilai karakter peserta didik. Hal ini juga terdapat dalam tujuan pendidikan nasional yang mengharapkan adanya sumber daya manusia yang berkualitas, mengembangkan potensi peserta didik agar menjadi manusia yang beriman dan bertaqwa kepada Tuhan Yang Maha Esa dalam kehidupan berbangsa dan bernegara. Oleh karena itu, pendidikan senantiasa bersifat menumbuhkembangkan nilai-nilai karakter

Setelah melakukan pengamatan selama satu semester ketika PKL di SMA Negeri 11 Padang ditambah pengamatan selama 3 hari sebelum mulai penelitian terlihat bahwa karakter peserta didik di SMA Negeri 11 Padang belum optimal. Hal ini terlihat dari sikap peserta didik selama proses pembelajaran berlangsung. Peserta didik masih banyak yang terlambat masuk kelas, berbicara, mengerjakan tugas lain, main $\mathrm{hp}$, dan keluar dengan teman baik itu berdua atau lebih ketika pembelajaran berlangsung sehingga karakter disiplin pada peserta didik masih belum berkembang. Ketika ada ujian harian maupun ujian tengah semester, peserta didik banyak yang tidak jujur karena masih adanya kerja sama, saling memberikan jawaban ketika ujian, dan masih ada yang melihat catatan. Ketika diberikan tugas, masih banyak peserta didik yang mengharapkan jawaban dari temannya. Peserta didik hanya menyalin tanpa bertanya dari mana jawaban soal tersebut. Disini terlihat bahwa karakter bertanggung jawab, kerja keras, dan rasa ingin tahu pada diri peserta didik belum berkembang, apalagi konsisten. Kondisi ini tentu cukup menghawatirkan apabila berlanjut. Untuk itu, guru perlu menumbuhkembangkan nilainilai karakter tersebut agar karakter peserta didik membaik dari hari ke hari.

Nilai-nilaii karakter yang perlu dikembangkan itu ada 18 nilai yang dapat dilihat pada Tabel $3^{[5] \text { : }}$

Tabel 3. Nilai Pendiidkan Budaya dan Karakter

\begin{tabular}{|ll|}
\hline \multicolumn{3}{|c|}{ Nilai Karakter } \\
\hline 1. & $\begin{array}{l}\text { Religius merupakan sikap taat pada ajaran } \\
\text { agamanya. }\end{array}$ \\
\hline 2. & $\begin{array}{l}\text { Jujur merupakan sikap yang selalu bertindak } \\
\text { sesuai dengan kenyataan. }\end{array}$ \\
\hline 3. & $\begin{array}{l}\text { Toleran merupakan sikap menghargai berbagai } \\
\text { pendapat yang berbeda dari pendapat diri sendiri. }\end{array}$ \\
\hline 4. & $\begin{array}{l}\text { Disiplin merupakan sikap tertib pada aturan yang } \\
\text { berlaku. }\end{array}$ \\
\hline 5. & $\begin{array}{l}\text { Kerja keras merupakan sikap berusaha } \\
\text { semaksimal mungkin dalam mencapai sesuatu. }\end{array}$ \\
\hline 6. & $\begin{array}{l}\text { Kreatif merupakan sikap yang berfikir sebelum } \\
\text { melakukan sesuatu, agar tindakan yang } \\
\text { dilakukan tidak sia-sia. }\end{array}$ \\
\hline
\end{tabular}

\section{Nilai Karakter}

7. Mandiri merupakan sikap berusajha sendiri tanpa mengharapkan bantuan dari orang lain.

8. Demokratis merupakan sikap yang menganggap semua manusia memiliki hak dan kewajiban yang sama.

9. Rasa ingin tahu merupakan sikap yang selalu merasa penasaran dan ingin tahu terhadap sesuatu yang diketahuinya.

10. Semagat kebangsaan merupakan sikap yang mengutamakan kepentingan bangsanya.

11. Cinta tanah air merupakan sikap mencintai tanah air diberbagai bidang.

12. Menghargai prestasi merupakan sikap yang mengahargai keberhasilan orang lain.

13. Bersahabat/komunikatif merupakan sikap bekerja sama dengan orang lain dan dapat memperlihatkan sikap yang baik saat bergaul dengan sesama.

14. Cinta damai merupakan sikap yang selalu berusaha menempatkan diri agar orang lain merasa aman bila berda di dekat dirinya.

15. Gemar membaca merupakan sikap yang selalu menyediakan waktu untuk membaca.

16. Peduli lingkungan merupakan sikap yang selalu menjaga kelestarian lingkungan dan menghindari tindakan yang dapat merusak lingkungan.

17. Peduli sosial merupakan sikap yang selalu berusaha untuk membantu sesama yang memerlukan bantuan.

18. Tanggung jawab meruapakan sikap yang selalu melakukan suatu tindakan yang dapat dipertanggung jawabkan.

Berdasarkan penjelasan pada Tabel 3 dapat diketahui nilai-nilai karakter bangsa itu ada 18 nilai, tetapi dalam penelitian ini, peneliti membatasi nilai karakter yang akan diamati selama penelitian karena keterbatasan waktu mengamati dan mengutamakan nilai-nilai karakter utama yang sangat penting untuk membentuk karakter yang baik bagi peserta didik yaitu: jujur, tanggung jawab, rasa ingin tahu, kerja keras, kerja sama, dan disiplin. Keenam nilai karakter ini merupakan nilai utama dalam mengembangkan sikap yang baik agar peserta didik dapat berkembang secara intelektual, pribadi, dan sosial. Nilai utama sekaligus menjadi budi utama adalah jujur, tanggung jawab, disiplin, kerja sama, dan peduli ${ }^{[6]}$.

Penanaman dan mengembangan sikap jujur membantu peserta didik untuk berkata dan berbuat sesuai dengan yang sebenarnya. Dengan sikap tanggung jawab, peserta didik akan belajar untuk siap menerima dan mengerjakan tugas serta mau menanggung konsekuensi dari tindakannya. Sikap kerja keras dan rasa ingin tahu mendorong peserta didik lebih aktif dalam belajar dan berusaha menyelesaikan tugas/ pekerjaan semaksimal mungkin. Kerja sama merupakan usaha yang terkoordinasi diantara setiap 
anggota kelompok yang diarahkan untuk mencapai tujuan bersama. Kerja sama adalah suatu bentuk interaksi sosial dimana tujuan anggota kelompok yang satu berkaitan erat dengan tujuan anggota kelompok yang lain ${ }^{[7]}$. Kemampuan kerja sama sangat diperlukan dalam menjalankan kehidupan sehari-hari baik di lingkungan sekolah, lingkungan keluarga, dan lingkungan masyarakat. Dalam penelitian ini, peneliti akan mengamati perubahan sikap kerja sama peserta didik dalam menyelesaikan tugas kelompoknya karena dalam proses pembelajaran menggunakan model pembelajaran diskusi secara berkelompok. Disiplin diri peserta didik bertujuan untuk mencegah dan mengatasi timbulnya masalahmasalah disiplin, serta menciptakan suasana aman, nyaman, dan menyenangkan dalam pembelajaran.

Nilai-nilai karakteryang diamati digali berdasarkan substansi materi yang diajarkan, misalnya pada materi usaha dan energi yang dipaparkan bahwa usaha yang dilakukan akan bernilai jika terjadi perubahan. Besarnya perubahan yang diperoleh dikarenakan adanya nilai kerja keras dalam materi tersebut dan apabila digali lebih lanjut akan menemukan nilai-nilai karakter yang diharapkan ada pada diri peserta didik.

Berdasarkan latar belakang di atas agar pembelajaran dapat mengoptimalkan aktivitas, kerja sama peserta didik, dan dapat menumbuhkembangkan karakter peserta didik yang baik, maka dalam penelitian model pembelajaran kooperatif yang dipilih adalah Jigsaw menggunakan LKS yang ber-muatan nilai-nilai karakter. Oleh sebab itu, penelitian ini diberi judul "Penerapan LKS Bermuatan Nilai-Nilai Karakter dalam Model Pembelajaran Kooperatif Tipe Jigsaw pada Kelas XI di SMA Negeri 11 Padang."

\section{METODE PENELITIAN}

Desain penelitian ini adalah Quasi Experiment dengan rancangan penelitian Randomized Control Group Only Design. Proses pembelajaran yang dilakukan pada kelas eksperimen menggunakan model pebelajaran kooperatif tipe Jigsaw berbantukan LKS yang bermuatan nilai-nilai karakter sedangkan proses pembelajaran pada kelas kontrol tetap menggunakan model pebelajaran kooperatiftipe Jigsaw, tetapi LKS yang digunakan merupakan LKS yang dipakai oleh guru di SMA Negeri 11 Padang.

Jenis penelitian Randomized Control Group Only Design dapat digambarkan pada Tabel $4^{[8]}$.

Tabel 4. Randomized Control Group Only Design

\begin{tabular}{|c|c|c|}
\hline Group & Treatment & Posttest \\
\hline Eksperimen & $\mathrm{X}$ & $\mathrm{T}$ \\
\hline Kontrol & - & $\mathrm{T}$ \\
\hline
\end{tabular}

Keterangan :

$\mathrm{X}=$ Perlakuan yang diberikan pada kelas eksperimen

$\mathrm{T}=$ Tes akhir yang dilakukan pada kelas eksperimen dan kelas kontrol.
Populasi penelitian adalah seluruh peserta didik kelas XI MIA SMANegeri 11 Padang yang terdaftar pada tahun ajaran 2014/2015 dengan sampel yang diambil secara cluster random sampling. Pengambilan sampel secara cluster random sampling merupakan pengambilan sampel pada populasi berdasarkankelompok-kelompok individu yang telah ada di sekolah yaitu kelas bukan secara individual. Setelah dilakukan teknik cluster random sampling maka didapat sampel pada penelitian yaitu kelas XI MIA1 sebagai kelas eksperimen dan kelas kelas XI MIA2 sebagai kelas kontrol.

Variabel dalam penelitian ini adalah: variabel bebas, variabel terikat, dan variabel kontrol. Variabel bebas merupakan variabel yang diperkirakan berpengaruh terhadap variable lain. Dalam penelitian ini yang menjadi variabel bebas adalah LKS yang bermuatan nilai-nilai karakter dalam model pembelajaran kooperatif tipe Jigsaw. Variabel terikat merupakan variabel yang dipengaruhi atau yang menjadi akibat karena adanya suatu variabel bebas. Variabel terikat dalam penelitian ini adalah hasil belajar Fisika peserta didik setelah diterapkan model pembelajaran kooperatif tipe Jigsaw menggunakan LKS bermuatan nilai-nilai karakter. Variabel kontrol merupakan variabel yang dibuat konstan dan dikendalikan sehingga hubungan antara variabel bebas dan variabel terikat tidak ter-pengaruh oleh faktor luar yang diteliti. Adapun variabel kontrol pada penelitian ini adalah: materi pelajaran yang sesuai dengan Kurikulum 2013, guru, buku sumber, waktu, kemampuan awal, dan jumlah soal yang diujikan pada kedua kelas adalah sama.

Data penelitian berupa data primer yang langsung diperoleh oleh peneliti dari kedua kelas sampel. Data primer didapat setelah diberikan perlakuan pada kedua kelas sampel yaitu: data kompetensi sikap diambil melalui lembar observasi. Data kompetensi pengetahuan diambil melalui tes tulis berupa soal pilihan ganda dan data kompetensi keterampilan diambil melalui rubrik penskoran.

Prosedur penelitian ada tiga yaitu: tahap persiapan, tahap pelaksanaan, dan tahap penyelesaian. Tahap persiapan dilakukan dengan menyusun LKS, menetapkan jadwal, menentukan kelas sampel, mempersiapkan perangkat pembelajaran seperti RPP dan LKS bermuatan nilai-nilai karakter, membuat kisi-kisi soal uji coba, dan mempersiapkan instrumen penelitian. Kedua tahap pelaksanaan dengan melaksanakan pembelajaran dimana kelas eksperimen menggunakan LKS bermuatan nilai-nilai karakter dalam model pembelajaran kooperatif tipe Jigsaw dan kelas kontrol menggunakan LKS dari sekolah dengan model pembelajaran kooperatif tipe Jigsaw. Terakhir tahap penyelesaian dengan me-lakukan uji coba soal tes akhir, menganalisis hasil uji coba soal dengan menentukan reliabilitas soal, indeks kesukaran dan daya beda soal kemudian melakukan tes akhir 
pada kedua kelas sampel yang bertujuan untuk mendapatkan hasil belajar peserta didik pada kompetensi pengetahuan. Setelah data hasil belajar peserta didik pada setiap kompetensi diperoleh maka dilakukan analisis data pada setiap kompetensi.

Instrumen penelitian pada kompetensi sikap berupa lembar observasi pada karakter yang diamati yaitu: jujur, disiplin, tanggung jawab, rasa ingin tahu, kerja keras, dan kerja sama selama proses pembelajaran sebanyak tujuh kali pertemuan. Instrumen kompetensi pengetahuan berupa tes tulis pilihan ganda sebanyak 25 soal dengan 5 pilihan jawaban. Instrumen kompetensi keterampilan berupa rubrik penskoran saat melakukan praktikum di laboratorium sebanyak 2 kali praktikum. Setelah semua data dari hasil belajar peserta didik pada setiap kompetensi maka dilakukan analisis data.

Analisis data bertujuan untuk menguji apakah hipotesis dalam penelitian diterima atau ditolak. Sebelum melakukan uji hipotesis maka dilakukan uji normalitas dan uji homogenitas. Uji normalitas bertujuan untuk mengetahui apakah sampel terdistribusi normal dengan menggunakan uji Lilliefors.Kriteria penerimaan terdistribusi normal jika $\mathrm{L}_{\mathrm{o}}$ lebih kecil dari $\mathrm{L}_{\mathrm{t}}$, selain dari itu ditolak.Setelah melakukan uji normalitas dilakukan uji homogenitas untuk menentukan kedua kelas sampel mempunyai varians yang homogen atau tidak. Uji homogenitas dilakukan dengan uji F. Data kedua kelas sampel dikatakan mempunyai varian yang homogen jika harga $F_{\text {tabel }}>F_{\text {hitung. }}$ Setelah diketahui kedua kelas sampel berasal dari populasi terdistribusi normal dan memiliki varian yang homogen, maka pengujian hipotesis dilakukan menggunakan uji $t$ dengan menggunakan persamaan ${ }^{[8]}$ :

$$
t=\frac{\overline{X_{1}}-\overline{X_{2}}}{S \sqrt{\frac{1}{n_{1}}}+\frac{1}{n_{2}}}
$$

Kriteria pengujian adalah terima $\mathrm{H}_{0}$ jika : $-t_{1-1 / 2^{\alpha}}<t<t_{1-1 / 2^{\alpha}}$ pada taraf signifikan 0,05 . Sedangkan untuk harga lainnya $\mathrm{H}_{\mathrm{o}}$ ditolak.

Teknik analisis data untuk kompetensi sikap dan kompetensi keterampilan terlebih dulu dilakukan konversi skor ke nilai dengan rumus pada persamaan $2^{[9]}$, kemudian dilakukan analisis seperti analisis yang dijelaskan di atas yaitu melakukan uji normalitas dan homogenitas.

$$
N a=\frac{S p}{S m} x 100 .
$$

\section{HASIL PENELITIAN DAN PEMBAHASAN \\ 1. Hasil Penelitian}

Data dalam penelitian yang diperoleh berupa hasil belajar peserta didik pada kompetensi sikap, pengetahuan, dan keterampilan. Hasil belajar pada kompetensi sikap diperoleh melalui observasi pada karakter yang diamati yaitu: jujur, disiplin, tanggung jawab, rasa ingin tahu, kerja keras, dan kerja sama selama tujuh kali pertemuan. Deskripsi hasil belajar kompetensi sikap dapat dilihat pada Tabel 5.

Tabel 5. Nilai Tertinggi, Nilai Terendah, Nilai Ratarata, Varian dan Simpangan Baku Kedua Kelas Sampel pada Kompetensi Sikap

\begin{tabular}{|c|c|c|c|c|c|c|}
\hline Kelas & $\mathrm{N}$ & $\begin{array}{c}\text { Nilai } \\
\text { Tertinggi }\end{array}$ & $\begin{array}{c}\text { Nilai } \\
\text { Terendah }\end{array}$ & $\bar{X}$ & $\mathrm{~S}^{2}$ & $\mathrm{~S}$ \\
\hline Eksperimen & 32 & 93 & 70 & 81,38 & 40,24 & 6,34 \\
\hline Kontrol & 31 & 90 & 58 & 68,90 & 68.89 & 8,3 \\
\hline
\end{tabular}

Berdasarkan Tabel 5 terlihat bahwa nilai ratarata kompetensi sikap kelas eksperimen lebih tinggi dibandingkan kelas kontrol. Nilai simpangan baku kelas eksperimen lebih kecil dari nilai simpangan baku kelas kontrol, ini berarti hasil belajar peserta didik pada kelas eksperimen lebih merata daripada kelas kontrol pada kompetensi sikap. Nilai varian kelas eksperimen lebih kecil dibanding nilai varian kelas kontrol, artinya hasil belajar kelas kontrol lebih beragam daripada kelas eksperimen.

Grafik penilaian sikap peserta didik dapat dilihat pada Gambar 1.

Kelas Ekperimen Kelas Kontrol

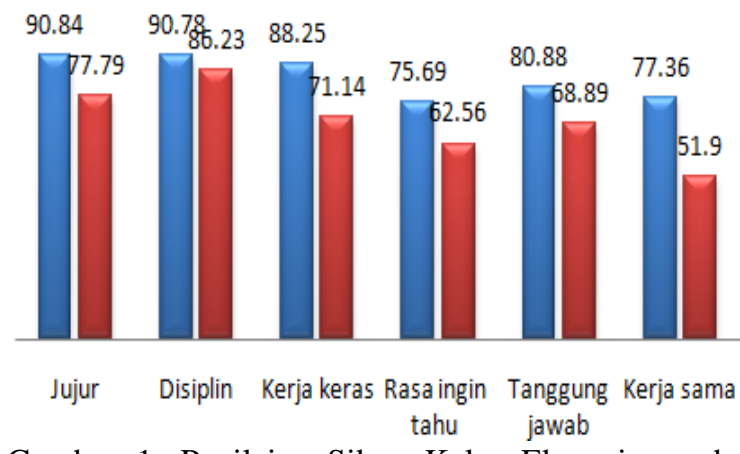

Gambar 1. Penilaian Sikap Kelas Eksperimen dan Kelas Kontrol

Berdasarkan Gambar 1 terlihat bahwa sikap peserta didik kelas eksperimen pada semua sikap yang diamati selama tujuh kali pertemuan lebih tinggi dibanding kelas kontrol dengan rata-rata sikap kelas eksperin adalah 83,97 dan rata-rata sikap kelas kontrol adalah 74,03.

Data kompetensi pengetahuan diperoleh dari tes akhir berupa soal objektif yang berjumlah 25 soal dengan lima pilihan jawaban. Deskripsi data hasil belajar kompetensi pengetahuan dapat dilihat pada Tabel 6 berikut ini.

Tabel 6. Nilai Tertinggi, Nilai Terendah, Nilai RataRata, Varians dan Simpangan Baku Kedua Kelas Sampel pada Kompetensi Pengetahuan

\begin{tabular}{|l|l|l|l|l|l|l|}
\hline Kelas & N & $\begin{array}{l}\text { Nilai } \\
\text { Tertinggi }\end{array}$ & $\begin{array}{l}\text { Nilai } \\
\text { Terendah }\end{array}$ & $\bar{X}$ & S $^{2}$ & S \\
\hline Eksperimen & 32 & 96 & 60 & 81 & 119,74 & 10,94 \\
\hline Kontrol & 31 & 96 & 60 & 75,23 & 130,58 & 11,43 \\
\hline
\end{tabular}


Berdasarkan Tabel 6 terlihat bahwa nilai ratarata peserta didik kelas eksperimen pada kompetensi pengetahuan lebih tinggi dibanding kelas kontrol. Nilai simpangan baku kelas eksperimen lebih kecil dibanding nilai simpangan baku kelas kontrol, artinya hasil belajar peserta didik pada kompetensi pengetahuan kelas eksperimen lebih merata daripada kelas kontrol. Nilai varian kelas eksperimen lebih kecil jika disbanding nilai varian kelas kontrol, artinya hasil belajar kompetensi pengetahuan kelas kontrol lebih beragam daripada kelas eksperimen.

Data hasil belajar peserta didik pada kompetensi keterampilan diperoleh dari rubrik penskoran selama proses pratikum di laboratorium berlangsung selama 2 kali praktikum. Deskripsi nilai keterampilan peserta didik untuk kedua kelas sampel dapat dilihat pada Tabel 7 berikut ini.

Tabel 7. Nilai Tertinggi, Nilai Terendah, Nilai RataRata, Variansi, dan Simpangan Baku Kedua Kelas Sampel pada Kompetensi Keterampilan

\begin{tabular}{|c|c|c|c|c|c|c|}
\hline Kelas & $\mathrm{N}$ & $\begin{array}{c}\text { Nilai } \\
\text { Tertinggi }\end{array}$ & $\begin{array}{c}\text { Nilai } \\
\text { Terendah }\end{array}$ & $\bar{X}$ & $S^{2}$ & $S$ \\
\hline Eksperimen & 32 & 90 & 60 & 74,78 & 111,53 & 10,56 \\
\hline Kontrol & 31 & 90 & 48 & 66,9 & 158,76 & 12,6 \\
\hline
\end{tabular}

Dari Tabel 7 terlihat bahwa rata-rata nilai hasil belajar kompetensi keterampilan kelas eksperimen lebih tinggi dibandingkan dengan kelas kontrol. Pada kompetensi keterampilan nilai simpangan baku kelas eksperimen lebih kecil dibanding nilai simpangan baku kelas kontrol, artinya hasil belajar peserta didik pada kompetensi keterampilan kelas eksperimen lebih merata daripada kelas kontrol. Nilai varian kelas eksperimen lebih kecil dibanding nilai varian kelas kontrol, artinya hasil belajar kompetensi keterampilan kelas kontrol lebih beragam dibandingkan pada kelas eksperimen.

Untuk mengetahui apakah hipotesis penelitian diterima atau ditolak maka dilakukan uji kesamaan dua rata-rata dengan melakukan uji normalitas dan homogenitas terlebih dulu. Uji normalitas dilakukan dengan uji Lilliefors sehingga didapat harga $L_{o}$ dan $L_{\text {tabel }}$ dengan taraf nyata 0,05 .

Berdasarkan uji normalitas dan homogenitas yang dilakukan pada kompetensi sikap, kompetensi pengetahuan, dan kompetensi keterampilan didapat data kedua kelas sampel terdistribusi normal dan memiliki varian yang homogen. Oleh karena itu, untuk menguji hipotesis digunakan uji t. Hasil uji t pada kompetensi sikap kedua kelas sampel dapat dilihat pada Tabel 8 .

Tabel 8. Hasil Uji Kesamaan Dua Rata-rataKedua Kelas Sampel pada Kompetensi Sikap

\begin{tabular}{|l|c|c|c|c|c|}
\hline \multicolumn{1}{|c|}{ Kelas } & $\mathrm{N}$ & $\bar{X}$ & $S^{2}$ & $t_{h}$ & $t_{t}$ \\
\hline Eksperimen & 32 & 81,38 & 40,24 & \multirow{2}{*}{6,79} & \multirow{2}{*}{1,98} \\
\hline Kontrol & 31 & 68,9 & 68.89 & & \\
\hline
\end{tabular}

Berdasarkan Tabel 8 terlihat $t_{\text {hitung }}=6,79$ dan $t_{\text {tabel }}=1,98$ pada taraf nyata 0,05 . Kriteria pengujian adalah terima $\mathrm{H}_{0}$ jika: $-t_{1-1 / 2^{\alpha}}<t<t_{1-1 / 2^{\alpha}}=-$ $1,98<6,79<1,98$ pada taraf signifikan 0,05. Artinya $\mathrm{H}_{0}$ diterima apabila $t_{\text {hitung }}$ terletak antara $-1,98$ dan 1,98. Karena $t_{\text {hitung }}$ berada diluar penerimaan $\mathrm{H}_{0}$, maka dapat disimpulkan bahwa Hipotesis Kerja $\mathrm{H}_{\mathrm{i}}$ diterima, yang berbunyi "Terdapat Pengaruh Yang Berarti pada Penerapan LKS Bermuatan Nilai-Nilai Karakter dalam Model Pembelajaran Kooperatif Tipe Jigsaw pada Kelas XI di SMA Negeri 11 Padang pada kompetensi sikap".

Hasil uji $t$ tes akhir kedua kelas sampel pada kompetensi pengetahuan dapat dilihat pada Tabel 8 .

Tabel 9. Hasil Uji Kesamaan Dua Rata-rata Tes Akhir Kedua Kelas Sampel padaKompetensi Pengetahuan

\begin{tabular}{|l|c|c|c|c|c|}
\hline \multicolumn{1}{|c|}{ Kelas } & $\mathrm{N}$ & $\bar{X}$ & $S^{2}$ & $t_{h}$ & $t_{t}$ \\
\hline Eksperimen & 32 & 81 & 119,74 & \multirow{2}{*}{2,06} & \multirow{2}{*}{1,98} \\
\cline { 1 - 3 } Kontrol & 31 & 75,23 & 130,58 & & $=2,06$
\end{tabular}

dan $t_{\text {tabel }}=1,98$ pada taraf nyata 0,05 . Berdasarkan kriteria pengujian disimpulkan bahwa Hipotesis Kerja $\mathrm{H}_{\mathrm{i}}$ diterima yang berbunyi "Terdapat Pengaruh Yang Berarti pada Penerapan LKS Bermuatan NilaiNilai Karakter dalam Model Pembelajaran Kooperatif Tipe Jigsaw pada Kelas XI di SMA Negeri 11 Padang pada kompetensi pengertahuan.

Hasil uji t pada kompetensi keterampilan kedua kelas sampel dapat dilihat pada Tabel 10.

Tabel 10. Hasil Uji Kesamaan Dua Rata-rataKedua Kelas Sampel pada Kompetensi Keterampilan

\begin{tabular}{|l|c|c|c|c|c|}
\hline \multicolumn{1}{|c|}{ Kelas } & $\mathrm{N}$ & $\bar{X}$ & $S^{2}$ & $t_{h}$ & $t_{t}$ \\
\hline Eksperimen & 32 & 74,78 & 111,53 & \multirow{2}{*}{2,72} & \multirow{2}{*}{1,98} \\
\cline { 1 - 4 } Kontrol & 31 & 66,9 & 158,76 & & \\
\hline
\end{tabular}

Berdasarkan Tabel 10 didapatkan $t_{\text {hitung }}$ adalah 2,72 dan $\mathrm{t}_{\text {tabel }}$ adalah 1,98 pada taraf nyata 0,05 . Karena $t_{\text {hitung }}$ berada diluar penerimaan $\mathrm{H}_{0}$, maka dapat disimpulkan bahwa Hipotesis Kerja $\mathrm{H}_{\mathrm{i}}$ diterima, yang berbunyi "Terdapat Pengaruh Yang Berarti pada Penerapan LKS Bermuatan Nilai-Nilai Karakter dalam Model Pembelajaran Kooperatif Tipe Jigsaw pada Kelas XI di SMA Negeri 11 Padang pada kompetensi keterampilan".

\section{Pembahasan}

Berdasarkan uji hipotesis terhadap hasil belajar Fisika peserta didik, terlihat bahwa penerapan LKS bermuatan nilai-nilai karakter dalam model pembelajaran kooperatif tipe Jigsaw dapat meningkatkan hasil belajar Fisika peserta didik, pada kompetensi 
sikap, kompetensi pengetahuan maupun kompetensi keterampilan. Hal ini dapat dilihat pada rata-rata nilai hasil belajar sikap, tes akhir, dan keterampilan peserta didik yang belajar dengan menggunakan LKS bermuatan nilai-nilai karakter dalam model pembelajaran kooperatif tipe Jigsaw, lebih baik dibanding dengan rata-rata nilai hasil belajar peserta didik yang belajar dengan me-nggunakan LKS dari sekolah tanpa bermuatan nilai-nilai karakter dalam dalam model pembelajaran kooperatif tipe Jigsaw.

Hasil belajar pada kompetensi sikap untuk keenam aspek penilaian didapar rata-rata nilai sikap kelas eksperimen adalah 81,38. Sedangkan rata-rata nilai kelas kontrol adalah 68,9. Pada setiap aspek nilai sikap yang diamati juga menunjukan kelas eksperimen lebih tinggi dibanding kelas kontrol. Sikap jujur kelas eksperimen lebih tinggi dibanding kelas kontrol. Begitu juga dengan sikap disiplin, kerja keras, tanggug jawab, kerja sama, dan rasa ingin tahu. Ini menunjukan bahwa aspek penilaian sikap peserta didik kelas eksperimen lebih baik dibanding kelas kontrol. Hal ini terlihat pada karakter peserta didik di kelas eksperimen terlihat tidak lagi mencontek saat mengerjakan tugas atau ujian, dan tidak mengerjakan pekerjaan lain ketika proses pembelajaran berlangsung. Setelah bel masuk berbunyi semua peserta didik telah duduk bersiap untuk memulai pembelajaran dan peserta didik menyelesaikan tugas tepat pada waktunya. Saat pembelajaran diskusi berlangsung peserta didik fokus pada pelajaran dengan membaca materi masing-masing, mengerjakan semua tugas masing-masing dan berkonsentrasi pada topik yang di-pelajari. Disini terlihat bahwa karakter kerja keras dan tanggung jawab peserta didik mulai berkembang. Ketika diskusi berlangsung peserta didik saling mem-bantu jika ada anggota kelompoknya yang kurang paham pada materi yang dibahas, bertanggung jawab atas bagian materi yang harus dipelajari dan me-nyampaikan kepada anggota kelompoknya. Diskusi dan proses pembelajaran lebih dinamis karena peserta didik antusias dalam bertanya pada materi yang tidak dipahaminya, baik bertanya pada guru maupun teman kelompoknya. Dengan demikian rasa ingin tahu dan kerja sama peserta didik semakin berkembang. Situasi kelas yang nyaman sangat mendukung dalam perubahan karakter peserta didik. Pendidikan berkarakter telah mencangkup pengembangan substansi, proses, dan suasana atau lingkungan yang menggugah, mendorong, dan dapat memudahkan seseorang dalam mengembangkan kebiasaan baik dalam kehidupan sehari-hari ${ }^{[10]}$.

Sementara itu, peserta didik di kelas kontrol terlihat peserta didik masih suka mencoktek saat mengerjakan tugas atau ujian. Mereka kurang fokus dalam proses pembelajaran. Beberapa peserta didik telihat mercerita, bermenung, asyik sendiri atau tidak peduli saat proses pembelajaran berlangsung. Pada karakter disiplin yang diamati, peserta didik masih ada yang tidak menyelesaikan tugas tidak pada waktu yang ditetapkan. Antusias peserta didik dalam diskusi dan kerja kelompok juga masih rendah. Kerja sama kurang terlihat. Tugas-tugas cendrung diselesaikan oleh peserta didik yang lebih pintar dan dianggap mampu oleh peserta didik yang lain. Peserta didik yang me-ngerti dengan materi pembelajaran lebih berperan aktif tanpa membagi ilmu dengan peserta didik yang pasif dan kurang mengerti materi pembelajaran. Semakin hari semakin terlihat karakter peserta didik di kelas kontrol tidak menunjukan perkembangan yang meningkat seperti halnya pada kelas eksperimen.

Perubahan nilai karakter peserta didik yang diamati oleh peneliti cukup berfluaktuasi. Hal ini dapat terjadi karena peserta didik berusaha menerapkan apa yang diajarkan dengan tetap melakukan penalaran moral yang diajarkan tesebut. Penalaran moral adalah serangkaian proses yang sistematis dalam mengevaluasi kebajikan dan mengembangkan pribadi yang konsisten dan tidak memihak serangkaian prinsip-prinsip moral yang digunakan untuk hidup. Penalaran moral tidak menjanjikan perubahan perilaku, tetapi merupakan komitmen pencarian jiwa individu dan refleksi pribadi atas kepercayaan, nilai, dan prinsipprinsip $^{[10]}$. Akan tetapi, proses ini sangat penting dalam meningkatkan pertumbuhan pengetahuan moral sehingga perubahan perilaku dapat terjadi sehingga konsintensi terhadap tindakan moral menjadi lebih besar dari proporsi yang seharusnya.

Hasil belajar pada kompetensi pengetahuan diperoleh dari rata-rata nilai hasil belajar yaitu ratarata kelas eksperimen adalah 80,25 dan rata-rata nilai kelas kontrol adalah 75,23. Dari rata-rata nilai kedua kelas sampel ini dapat dikatakan bahwa hasil belajar Fisika peserta didik yang menggunakan LKS bermuatan nilai-nilai karakter lebih baik di-bandingkan dengan pembelajaran yang menggunakan LKS dari sekolah. Dilihat dari ketuntasan peserta didik secara individu, sebanyak 18 dari 32 peserta didik kelas eksperimen telah memenuhi Kriteria Ketuntasan Minimal (KKM) yang ditetapkan oleh pihak sekolah yaitu 78,00. Dengan kata lain ketuntasan secara klasikal kelas ekperimen mencapai 56,25 \% dari jumlah peserta didik. Sedangkan pada kelas kontrol sebanyak 20 peserta didik belum memenuhi KKM. Ketuntasan klasikal kelas kontrol hanya mencapai $38,71 \%$ jumlah peserta didik. Jadi, peserta didik kelas eksperimen yang memperoleh nilai di atas KKM lebih banyak dari kelas kontrol. Hal ini juga membuktikan bahwa hasil belajar kelas ekperimen lebih tinggi dari kelas kontrol.

Pengaruh sekolah terhadap perkembangan peserta didik, ditemukan satu hal penting yaitu bila peserta didik memiliki karakter yang baik, akan berpengaruh langsung terhadap prestasi akademik yang 
tinggi ${ }^{[10]}$. Karakter yang baik membantu peserta didik lebih mudah menghadapi tantangan kehidupan termasuk tantangan untuk berhasil secara akademis.

Peningkatan hasil belajar peserta didik pada kompetensi keterampilan terlihat saat peserta didik melakukan praktikum di laboratorium sebanyak 2 kali praktikum. Hasil belajar peserta didik pada kompetensi keterampilan didapat rata-rata nilai kelas eksperimen adalah 74,78. Sedangkan pada kelas control rata-rata nilai ke-terampilanya adalah 66,9. Berdasarkan data pada nilai praktek peserta didik pad kelas sampel terlihat bahwa nilai praktek pada kelas eksperimen maupun kontrol sama-sama meningkat, tetapi rata-rata nilai kelas eksperimen tetap lebih tinggi dibandingkan dengan kelas kontrol. Tingginya nilai pada kelas eksperimen didukung oleh perubahan nilai-nilai karakter yang telah diterapkan di kelas sebelumnya dimana peserta didik telah terbiasa bekerja sama, bekerja keras, dan bertanggung jawab terhadap tugas masing-masing yang diberikan sehingga pengerjaan pratikum dapat dilakukan dengan cepat dan tepat serta dimengerti oleh setiap anggota kelompok yang bersangkutan.

Berdasarkan hasil pengamatan yang peneliti lakukan selama penelitian, di SMA Negeri 11 Padang terlihat bahwa peserta didik lebih bersemangat, aktif, dan lebih berpartisipasi saat proses pembelajaran berlangsung. Berdasarkan uraian di atas, dapat diketahui bahwa LKS bermuatan nilai-nilai karakter merupakan bahan ajar yang dapat meningkatkan hasil belajar peserta didik pada ketiga kompetensi yaitu sikap pesera didik yang membaik dari hari ke hari, nilai ujiannya yang lebih bagus, serta keterampilan dalam pratikum di laboratorium lebih bagus. Dengan didukungnya penggunaan LKS bermuatan nilai-nilai karakter dalam model pembelajaran kooperatif tipe Jigsaw dapat mengaktifkan peserta didik dalam pembelajaran. Dengan model ini, peserta didik dibiasakan untuk menemukan sendiri konsep Fisika. Selain itu, kemampuan sosial peserta didik juga dikembangkan melalui diskusi dan kerja sama dalam kelompok sehingga peserta didik terlatih dalam sikap menghargai teman, menanggapi pendapat orang lain dengan cara yang baik, serta mampu berbicara di depan orang banyak melalui presentasi kelas. Oleh karena itu, jelas LKS bermuatan nilai-nilai karakter dalam model pembelajran koperatif tipe Jigsaw dapat meningkatkan hasil belajar Fisika peserta didik pada ketiga kompetensi.

Pentingnya pendididikan berkarakter yang terintegrasi dalam pembelajaran Fisika yaitu untuk membentuk manusia seutuhnya. Nilai-nilai karakter ini tidak berkesan sebagai mata pelajaran terpisah yang bersifat formalitas, tetapi tertanam dalam pribadi peserta didik karena diterapkan langsung dalam proses pembelajaran sehingga tercipta peserta didik yang cerdas dan berkarakter. Hal ini senada dengan tujuan pendidikan yaitu agar pendidikan tidak hanya membentuk insan Indonesia yang cerdas, tetapi juga berkepribadian atau berkarakter ${ }^{[11]}$.

\section{KESIMPULAN}

Setelah dilakukan penelitian dan analisis data terhadap Penerapan LKS Bermuatan Nilai-Nilai Karakter dalam Model Pembelajaran Kooperatif Tipe Jigsaw pada Kelas XI di SMA Negeri 11 Padangdapat disimpulkan bahwa Penerapan LKS Bermuatan nilai-nilai karakter dalam Model Pembelajaran Kooperatif Tipe Jigsaw memberikan pengaruh terhadap hasil belajar Fisika peserta didik pada ketiga kompetensi yaitu kompetensi sikap, kompetensi pengetahuan, dan kompetensi keterampilan di kelas XI SMA Negeri 11 Padang pada taraf nyata 0,05 .

\section{DAFTAR PUSTAKA}

[1]. Permendikbud nomor 103.2014. Salinan Lampiran Peraturan Menteri Pendidikan Dan Kebudayaan Republik Indonesia Nomor 103 Tahun 2014 Tentang Pembelajaran Pada Pendidikan Dasar Dan Pendidikan Menengah. Jakarta.

[2]. Prastowo, Andi. 2011. Panduan Kreatif Membuat Bahan Ajar Inovatif Menciptakan Metode Pembelajaran yang Menarik dan Meyenangkan. Jogjakarta: DIVA Press.

[3]. Rusman. 2012. Model-Model Pembelajaran Mengembangkan Profesionalisme Guru. Jakarta: PT Raja Grafindo Persada.

[4]. Eggen, Paul, Don Kauchak. 2012. Strategi dan Model Pembelajaran. Jakarta: PT Indeks.

[5]. Kementrian Pendidikan Nasional. 2010. Pengembangan Pendidikan Budaya dan Karakter.

[6]. Ikhwanuddin. 2012 Implementasi Pendidikan Karakter Kerja Keras dan Kerja Sama dalam Perkuliahan. Yogyakarta: FT Universitas Negeri Yogyakarta.

[7]. Lukita, dkk. 2012. Teori kerja Sama dan Persaingan Kelompok. Diakse dari http://imadiklus.com/teori-kerjasama-dan persaingan-kelompok/. Tanggal 11 Januari 2014.

[8]. Djamas, Djusmaini. 2012. Mata Kuliah Metodologi Penelitian Dan Publikasi. Padang: FMIPA UNP.

[9]. Arikunto, Suharsimi. 2008. Dasar-Dasar Evaluasi Pendidikan. Jakarta: Bumi Aksara.

[10]. Zubaedi. 2011. Desain Pendidikan Karakter: Konsepsi dan Aplikasinya dalam Lembaga Pendidikan. Jakarta: Kencana.

[11]. Asmani, Jamal Ma'mur. 2011. Buku Panduan Internalisasi Pendidikan Karakter di Sekolah. Jogjakarta: DIVA Press. 